
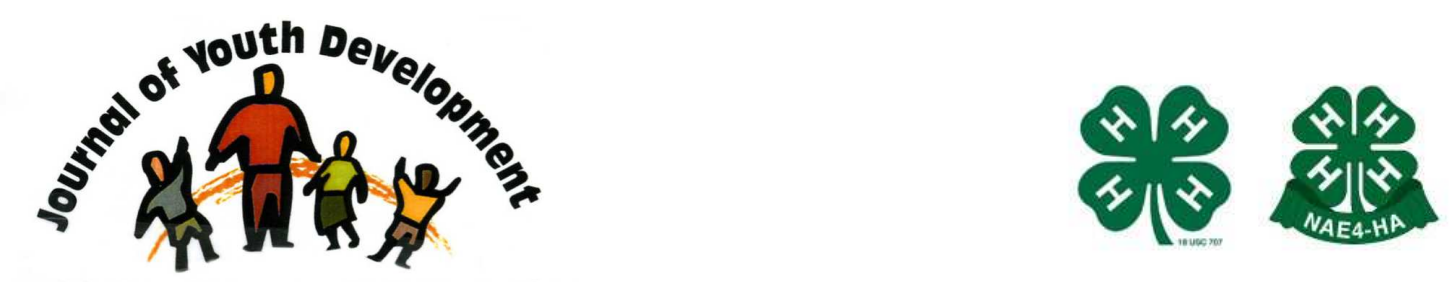

Bridging Research \& Practice

\title{
Parental Perceptions of Participation in 4-H Beef, Sheep and Swine Livestock Projects and the Fostering of Life Skill Development in Youth
}

\author{
Janice Heavner \\ WVU Pendleton County Extension \\ West Virginia University Extension Service \\ Franklin, WV \\ Janice.Heavner@mail.wvu.edu \\ Kelly Hicks \\ WVU Hampshire County Extension \\ West Virginia University Extension Service \\ Romney, WV \\ Kelly.Hicks@mail.wvu.edu \\ Shanna Nicodemus \\ WVU Jefferson County Extension \\ West Virginia University Extension Service \\ Kearneysville, WV \\ Shanna.Nicodemus@mail.wvu.edu
}




\title{
JOURNAL OF YOUTH DEVELOPMENT \\ bridging research and practice

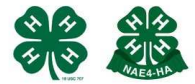

Bridging Research \& Practice

Volume 6, Number 2, Summer 2011

Article 110602PA002

\section{Parental Perceptions of Participation in 4-H Beef, Sheep and Swine Livestock Projects and the Fostering of Life Skill Development in Youth}

\author{
Janice Heavner, Kelly Hicks and Shanna Nicodemus \\ West Virginia University Extension Service
}

\begin{abstract}
Beef, sheep and swine 4-H youth livestock projects have a great deal of hands-on learning opportunities for members. However, what are parents' perceptions about livestock projects and the development of life skills? The purpose of this research effort was to determine the life skill development gained by $4-\mathrm{H}$ members participating in 4-H beef, sheep or swine projects in West Virginia. A total of 207 caregivers offered insight into the study and answered life skill development questions. These questions were related to decision making, relating to others, developing and maintaining records, accepting responsibility, building positive self esteem, self motivation, knowledge of the livestock industry, developing organizational skills, problem solving, developing oral communication skills, setting goals, developing self-discipline, and working in teams. The findings of this study provide positive insights into the relationship between the development of valuable life skills and 4-H beef, sheep and swine projects.
\end{abstract}

\section{Introduction}

4- $\mathrm{H}$, the largest informal youth organization in the world, promotes hands on learning opportunities for its members that instill life skills. 4-H also recognizes and rewards members for their hard work and perseverance. However, it is important to look past ribbons, trophies, trips, and monetary gains and examine the life skills that are being developed as a direct result of participation in livestock projects. The $4-\mathrm{H}$ youth livestock projects prove to have a great deal of hands-on learning opportunities for members. However, what are parents' perceptions about livestock projects and the development of life skills? Do parents feel that 4-H beef, sheep or swine projects are directly linked to their child's development? 
According to Boleman, Briers, and Cummings (2004), the parents of youth participating in the 4-H beef project did suggest that life skills are being enhanced. They also indicated that there is indeed a low to moderate positive relationship between years of participation and life skill development. According to Boyd, Herring, and Briers (1992), the development of life skills through experiential learning is the cornerstone of the 4-H program. The literature proves that many studies have been executed finding that youth do gain life skills through 4-H livestock projects. Building responsibility, relating to others, spirit of inquiry, decision making, public speaking, maintaining records, and building self esteem are the seven life skills that Ward's (1996) study of 4-H alumni revealed as the skills built through 4-H participation.

\section{Purpose and Objectives}

The purpose of this research effort was to determine the life skill development gained by 4-H members participating in 4-H beef, sheep, or swine projects in West Virginia. This was measured by asking parents/caregivers to address the life skill development of the child.

The objectives were:

1. Determine the life skills gleaned by youth participation in 4-H livestock projects as addressed by their parents/caregivers.

2. Measure the relationship between individual life skills and years of youth participation in 4- $\mathrm{H}$ livestock projects as addressed by their parents/caregivers.

\section{Methods and Procedures}

This research effort was approved by the Institutional Review Board-Human Subjects in Research, West Virginia University for exemption. The target population was defined as parents of 4- $\mathrm{H}$ youth participating in 4-H livestock projects. West Virginia's fifty-five counties with 4-H programming were invited to participate in the research study. A $10 \%$ random sample was drawn from the fifty-five counties.

Constructed to discover the perceived life skills gleaned from youth participation in 4-H livestock projects, a mailed questionnaire was used to collect the data. The following life skills were measured as part of the instrument:

1. Decision making

2. Ability to relate to others

3. Develop and maintain records

4. Accepting responsibility

5. Build positive self esteem

6. Self motivation

7. Knowledge of the livestock industry

8. Develop organizational skills

9. Ability to problem solve

10. Develop oral communication skills

11. Setting goals

12. Develop self-discipline

13. Work in teams 
The instrument was developed by Boleman et al. (2004) but modified and updated with input from 8 West Virginia University faculty members (See Appendix A). More specifically, these faculty members included: members from the Extension Agricultural and Natural Resources program center, members from the 4-H Youth Development program center and members from Family and Consumer Sciences program center. As suggested by Boleman et al. (2004) and Gall et al. (1996), face and content validity were assessed by these 8 individuals.

Parents/caregivers were asked to offer their perceptions of the level of life skill development as a result of their child raising a $4-\mathrm{H}$ livestock project. The scale was slightly modified from the Boleman et al. (2004) instrument and was defined as Not influential at all, Mildly influential, Moderately influential, Highly influential, and Essential. The years of youth participation and demographic information followed in the second instrument section.

Eleven junior 4-H leaders from Jefferson County were utilized to pilot the research tool and assess for research face validity. Three noted there was confusing wording in the demographic section. Additionally, the eleven junior 4-H leaders were asked to complete the instrument and return it to the investigator with only the provided instructions. Reliability, or internal consistency, of the life skill development scale was estimated from these data.

\section{Data Analysis}

\section{Demographics:}

The respondents were asked to provide how many years their child had been exhibiting livestock projects; the age and gender of their child; the number of livestock shows in which their child exhibited from January 2006 - August 2006; the number of hours their child had spent working with their livestock project(s) per week from January 2006 - August 2006; and the number of years their child had been in the 4-H program.

Of the 207 parents that responded, two did not provide the number of years their child had been exhibiting livestock projects; six did not provide the number of shows in which their child had exhibited from January 2006 - August 2006; two parents did not provide the number of hours their child worked with their livestock project(s); and three did not provide the number of years their child had been involved with the 4-H program.

Two hundred and five parents (99.0\%) reported that their children have been exhibiting for an average of 4.74 years with a range from 1 to 16 years. The mean age of the children was 13.75, a range from 6 to 24 years old. Ninety-three (44.9\%) male children and $114(55.1 \%)$ female children's parents responded to the questionnaire.

Two hundred and one (97.1\%) parents provided data on the number of shows in which their child exhibited from January 2006 - August 2006. Three parents (1.4\%) responded that their child had not showed at a livestock exhibition as a 4-H member to date. One hundred -seventy two $(85.6 \%)$ parents/caregivers stated that their child had participated in one to four livestock shows between January 2006 and August 2006, with a range of zero to 16 shows.

An average of 9-12 hours was stated to have been spent working with youth livestock projects per week from January 2006 - August 2006. The mean 4-H membership year was 5.30 $(11.3 \%)$, with a range from 2 to 16 years. 
Rating of Life Skills:

Parents' Perceptions of Life Skills Gained from Youth Exhibiting Livestock Projects

\section{Objective 1:}

Parents rated their child's livestock experience on a 5 point scale as follows: $1=$ Not influential at all, 2=Mildly influential, *3=Moderately influential, *4=Highly influential, *5=Essential N= 207

\begin{tabular}{|l|c|}
\hline Life Skill & $\begin{array}{c}\text { *Moderately Influential } \\
\text { and above }\end{array}$ \\
\hline Decision Making & $95 \%$ \\
\hline Ability to Relate to Others & $93.7 \%$ \\
\hline Develop and Maintain Records & $94.2 \%$ \\
\hline Accepting Responsibility & $99.5 \%$ \\
\hline Build Positive Self Esteem & $97.6 \%$ \\
\hline Self Motivation & $97.1 \%$ \\
\hline Knowledge of Livestock Industry & $94.7 \%$ \\
\hline Develop Organizational Skills & $97 \%$ \\
\hline Ability to Problem Solve & $94.2 \%$ \\
\hline Develop Oral Communication Skills & $88.9 \%$ \\
\hline Setting Goals & $97.6 \%$ \\
\hline Develop Self Discipline & $95.5 \%$ \\
\hline Develop Self Motivation & $96.6 \%$ \\
\hline Work in Teams & $91.8 \%$ \\
\hline
\end{tabular}

*Moderately influential, Highly Influential and Essential were totaled to determine life skill impact.

-In further examination of the chart above, one observes that impact is significant in the development of life skills when assuming a 4-H livestock project. As indicated in the chart, all life skill categories are consistently.

Parents rated their child's 4-H livestock experience on a 5 point scale as follows: $1=$ Not influential at all, 2=Mildly influential, *3=Moderately influential, *4=Highly influential, *5=Essential

\begin{tabular}{|l|c|}
\hline Life Skill & $\begin{array}{c}\text { *Highly Influential and } \\
\text { above }\end{array}$ \\
\hline Decision Making & $70.4 \%$ \\
\hline Ability to Relate to Others & $67.6 \%$ \\
\hline Develop and Maintain Records & $80.2 \%$ \\
\hline Accepting Responsibility & $91.8 \%$ \\
\hline Build Positive Self Esteem & $83.6 \%$ \\
\hline Self Motivation & $83 \%$ \\
\hline Knowledge of Livestock Industry & $79.2 \%$ \\
\hline Develop Organizational Skills & $69.2 \%$ \\
\hline Ability to Problem Solve & $63.3 \%$ \\
\hline Develop Oral Communication Skills & $58.3 \%$ \\
\hline Setting Goals & $81.1 \%$ \\
\hline Develop Self Discipline & $79.2 \%$ \\
\hline Develop Self Motivation & $82 \%$ \\
\hline Work in Teams & $66.7 \%$ \\
\hline
\end{tabular}

* Highly Influential and Essential were totaled to determine life skill impact. 
-One observes that impact proves to be very high in all categories in life skill development. These categories are consistent and high due to increased activities encompassed when assuming a 4-H livestock project.

-Accepting responsibility, with $91.3 \%$, proves to be very high. Raising a 4-H livestock project increases the level of daily work. Daily activities consume a large amount of time and can include walking the animal and maintaining a feeding program.

-Develop oral communication skills proves to be the lowest life skill developed, but is still significant at $58.3 \%$. This could be low because $4-\mathrm{H}$ members do not practice oral skills in the livestock fair arena. An oral project demonstration takes place in the 4-H club setting. Senior 4-H members further develop communication skills by giving oral reasons during livestock judging events.

\section{Correlation of Life Skills and Demographics:}

\section{Objective 2:}

Correlation was calculated utilizing a grand mean of the life skills and the individual demographics. Pearson's correlation is used to find the correlation between at least two continuous variables. Correlation was calculated for the grand mean of life skills and the individual demographics. The value for a Pearson's can fall between 0.00 (no correlation) and 1.00 (perfect correlation). Other factors such as group size will determine if the correlation is significant.

\begin{tabular}{|l|c|c|c|}
\hline Demographic & $\boldsymbol{N}$ & $\begin{array}{c}\text { Pearson } \\
\text { Correlation }\end{array}$ & $\begin{array}{c}\text { Significant } \\
\text { (2-tailed) }\end{array}$ \\
\hline $\begin{array}{l}\text { How many years has your child been } \\
\text { exhibiting livestock projects? }\end{array}$ & 189 & 0.185 & $\mathbf{0 . 1 1 *}$ \\
\hline How old is your child? & 190 & 0.144 & $\mathbf{0 . 0 4 8 *}$ \\
\hline What is the gender of your child? & 190 & 0.170 & $\mathbf{0 . 0 1 9 *}$ \\
\hline $\begin{array}{l}\text { How many shows did your child exhibit } \\
\text { livestock animals in from January 2006 } \\
\text { thru August 2006? }\end{array}$ & 184 & 0.204 & $\mathbf{0 . 0 0 5 * *}$ \\
\hline $\begin{array}{l}\text { How many hours did your child spend } \\
\text { working with his/her livestock project(s) } \\
\text { per week from January 2006 thru August } \\
\text { 2006? }\end{array}$ & 188 & -0.042 & 0.570 \\
\hline $\begin{array}{l}\text { How many years had your child been in } \\
\text { the 4-H program? }\end{array}$ & 187 & 0.186 & $\mathbf{0 . 0 1 1 *}$ \\
\hline
\end{tabular}

*Note: Significant|2-tailed - significant if $<.05$.

**Note: Significant/2- tailed - significant if <.01.

-The highest ranking life skill, Accepting Responsibility, did not significantly correlate with any of the demographics. The lowest ranking life skill, Develop Oral Communication Skills, did have a significant correlation with years of $4-\mathrm{H}$ membership and years of exhibiting livestock animals.

-The following tables show the significant correlation relationship between the individual life skills and the demographics. 


\begin{tabular}{|l|c|c|c|}
\hline $\begin{array}{l}\text { How many years has your child been } \\
\text { exhibiting livestock projects? }\end{array}$ & $\boldsymbol{N}$ & $\begin{array}{c}\text { Pearson } \\
\text { Correlation }\end{array}$ & $\begin{array}{c}\text { Significant } \\
\text { (2-tailed) }\end{array}$ \\
\hline Decision Making & 201 & 0.163 & $\mathbf{0 . 0 2 1 *}$ \\
\hline Knowledge of Livestock Industry & 205 & 0.175 & $\mathbf{0 . 0 1 2 *}$ \\
\hline Develop Oral Communication Skills & 204 & 0.145 & $\mathbf{0 . 0 3 9 *}$ \\
\hline Develop Self Discipline & 200 & 0.152 & $\mathbf{0 . 0 3 2 *}$ \\
\hline
\end{tabular}

*Note: Significant|2-tailed - significant if <.05.

\begin{tabular}{|l|c|c|c|}
\hline How old is your child? & $\boldsymbol{N}$ & $\begin{array}{c}\text { Pearson } \\
\text { Correlation }\end{array}$ & $\begin{array}{c}\text { Significant } \\
\text { (2-tailed) }\end{array}$ \\
\hline Knowledge of Livestock Industry & 207 & 0.146 & $\mathbf{0 . 0 3 6 *}$ \\
\hline
\end{tabular}

*Note: Significant|2-tailed - significant if <.05.

\begin{tabular}{|l|c|c|c|}
\hline What is the gender of your child? & $\boldsymbol{N}$ & $\begin{array}{c}\text { Pearson } \\
\text { Correlation }\end{array}$ & $\begin{array}{c}\text { Significant } \\
\text { (2-tailed) }\end{array}$ \\
\hline Ability to Relate to Others & 207 & 0.142 & $\mathbf{0 . 0 4 1 *}$ \\
\hline Develop and Maintain Records & 204 & 0.188 & $\mathbf{0 . 0 0 7 * *}$ \\
\hline Develop Organizational Skills & 205 & 0.165 & $\mathbf{0 . 0 1 8 *}$ \\
\hline Work in Teams & 207 & 0.147 & $\mathbf{0 . 0 3 5 *}$ \\
\hline
\end{tabular}

*Note: Significant|2-tailed - significant if $<.05$.

**Note: Significant/2- tailed - significant if <.01.

\begin{tabular}{|l|c|c|c|}
\hline $\begin{array}{l}\text { How many shows did your child } \\
\text { exhibit livestock animals in from } \\
\text { January 2006 thru August 2006? }\end{array}$ & N & $\begin{array}{c}\text { Pearson } \\
\text { Correlation }\end{array}$ & $\begin{array}{c}\text { Significant } \\
\text { (2-tailed) }\end{array}$ \\
\hline Ability to Relate to Others & 201 & 0.141 & $\mathbf{0 . 0 4 7 *}$ \\
\hline Develop and Maintain Records & 198 & 0.140 & $\mathbf{0 . 0 4 9 *}$ \\
\hline Self Motivation & 199 & 0.152 & $\mathbf{0 . 0 3 2} *$ \\
\hline Develop Organizational Skills & 199 & 0.178 & $\mathbf{0 . 0 1 2 *}$ \\
\hline Ability to Problem Solve & 201 & 0.206 & $\mathbf{0 . 0 0 3 * *}$ \\
\hline Setting Goals & 200 & 0.150 & $\mathbf{0 . 0 3 4 *}$ \\
\hline Develop Self Discipline & 196 & 0.196 & $\mathbf{0 . 0 0 6 * *}$ \\
\hline Develop Self Motivation & 200 & 0.185 & $\mathbf{0 . 0 0 9 * *}$ \\
\hline
\end{tabular}

*Note: Significant|2-tailed - significant if $<.05$.

**Note: Significant/2- tailed - significant if <.01.

\begin{tabular}{|l|c|c|c|}
\hline $\begin{array}{l}\text { How many hours did your child } \\
\text { spend working with his/her } \\
\text { livestock project(s) per week from } \\
\text { January 2006 thru August 2006? }\end{array}$ & N & $\begin{array}{c}\text { Pearson } \\
\text { Correlation }\end{array}$ & $\begin{array}{c}\text { Significant } \\
\text { (2-tailed) }\end{array}$ \\
\hline Self Motivation & 203 & -0.207 & $\mathbf{0 . 0 0 3 * *}$ \\
\hline
\end{tabular}

**Note: Significant/2- tailed - significant if $<.01$

-The relationship between hours spent working with the livestock project and self motivation is as follows: as self motivation increases, less time is spent working with livestock project.

\begin{tabular}{|l|c|c|c|}
\hline $\begin{array}{l}\text { How many years had your child been } \\
\text { in the 4-H program? }\end{array}$ & $\boldsymbol{N}$ & $\begin{array}{c}\text { Pearson } \\
\text { Correlation }\end{array}$ & $\begin{array}{c}\text { Significant } \\
\text { (2-tailed) }\end{array}$ \\
\hline Decision Making & 200 & 0.154 & $\mathbf{0 . 0 2 9 *}$ \\
\hline Knowledge of Livestock Industry & 204 & 0.213 & $\mathbf{0 . 0 0 2 * *}$ \\
\hline Develop Oral Communication Skills & 203 & 0.154 & $\mathbf{0 . 0 2 8 *}$ \\
\hline Develop Self Discipline & 199 & 0.142 & $\mathbf{0 . 0 4 6 *}$ \\
\hline
\end{tabular}

$*$ Note: Significant|2-tailed - significant if $<.05$.

**Note: Significant/2- tailed - significant if <.01. 


\section{Conclusion}

Parents participating in this research endeavor noted that life skills are being positively enhanced by participation in the $4-\mathrm{H}$ beef, sheep or swine project. The demographics and life skills correlation maintains the findings of Boleman, Briers, and Cummings (2004) that the longer children actively engage in the 4-H beef, sheep or swine project, the more likely they are developing positive life skills. Because of this life skill development, $4-\mathrm{H}$ is playing a major role in the cultivation of productive and contributing members of society.

It is commonly stated that 4-H programming increases life skill development in our youth; however, most 4-H professionals cannot state the exact life skills honed through various 4-H activities. This study strived to investigate the life skills that livestock programming, specifically beef, sheep and swine 4-H projects, cultivate in youth. According to the parents that participated in the study, the life skills that revealed significantly high correlation included: Accepting Responsibility, Building Positive Self Esteem, Self Motivation, Setting Goals, and Developing Organizational Skills.

These results proved to be powerful and significant to our youth development work. As agents of positive change, it is our responsibility to focus on the development of life skills and what 4-H projects, programs, etc., foster their development. While this research was designed for a target group of individuals, we know that positive youth development is occurring through involvement in beef, sheep and swine 4-H projects. Because the development of these life skills among members is the ultimate goals, we must further examine other $4-\mathrm{H}$ projects and strive to determine if life skill development is occurring.

\section{References}

Boleman, C., Cummings, S., Briers, G. (2004). Parents' Perceptions of Life Skills Gained by Youth Participating in the 4-H Beef Project. Journal of Extension, 42(5). Retrieved January 19, 2005, Available at: http://www.joe.org/joe/2004august/rb6.html

Boyd, B., Herring, D., Briers, G. (1992). Developing Life Skills in Youth. Journal of Extension, 30(4). Retrieved October 26, 2005, Available at: http://www.joe.org/joe/1992winter/a4.html

Gall, M.D., Borg, W.R., \& Gall, J.P. (1996). Educational research: An introduction (6 ${ }^{\text {th }}$ ed.). White Plains, NY: Longman Publishers USA.

Ward, C. (1996). Life Skill Development Related to Participation in 4-H Animal Science Projects. Journal of Extension, 34 (2). Retrieved October 26, 2005, Available at: http://www.joe.org/joe/1996april/rb2.html

(C) Copyright of Journal of Youth Development Bridging Research and Practice. Content may not be copied or emailed to multiple sites or posted to a listserv without copyright holder's express written permission. However, users may print, download or email articles for individual use. 


\section{Appendix A}

\section{Parents' Perceptions of Life Skills Developed by Participation with 4-H Youth Livestock Projects \\ Evaluation 2006}

\section{County}

\section{Life Skills Gained from Youth Exhibiting Livestock Projects}

The major objective of this study is to assess the characteristics gained from youth exhibiting livestock projects. Please provide a response for the following skills.

Rate the level of influence livestock showing has on the following life skills listed below. Please place an " $x$ " in the most appropriate box for each skill.

\begin{tabular}{|l|l|l|l|l|l|}
\hline LIFE SKILLS & $\begin{array}{c}\text { Not Influential } \\
\text { at all }\end{array}$ & $\begin{array}{c}\text { Mildly } \\
\text { influential }\end{array}$ & $\begin{array}{c}\text { Moderately } \\
\text { influential }\end{array}$ & Highly influential & Essential \\
\hline Decision Making & & & & & \\
\hline $\begin{array}{l}\text { Ability to } \\
\text { Relate to Others }\end{array}$ & & & & & \\
\hline $\begin{array}{l}\text { Develop } \\
\text { and Maintain Records }\end{array}$ & & & & & \\
\hline Accepting Responsibility & & & & & \\
\hline Build Positive Self Esteem & & & & & \\
\hline Self Motivation & & & & & \\
\hline $\begin{array}{l}\text { Knowledge } \\
\text { of Livestock Industry }\end{array}$ & & & & & \\
\hline $\begin{array}{l}\text { Develop } \\
\text { Organizational Skills }\end{array}$ & & & & & \\
\hline Ability to Problem Solve & & & & & \\
\hline $\begin{array}{l}\text { Develop Oral } \\
\text { Communication Skills }\end{array}$ & & & & & \\
\hline Setting Goals & & & & & \\
\hline Develop Self-Discipline & & & & & \\
\hline Develop Self Motivation & & & & & \\
\hline Work in Teams & & & & & \\
\hline
\end{tabular}

\section{Background Information}

Please place the most appropriate response in the blank.

1. How many years has your child been exhibiting livestock projects?

2. How old is your child?

3. What is the gender of your child? Male OR Female

4. How many shows did your child exhibit livestock animals in from January 2006 thru August 2006?

$\begin{array}{ll}\text { 1-4 Shows } & \text { 13-16 Shows } \\ \text { 5-8 Shows } & \text { 17-20 Shows } \\ \text { 9-12 Shows } & \text { More than } 20 \text { Shows }\end{array}$

5. How many hours did your child spend working with his/her livestock projects(s) per week from January 2006 - August 2006?

1-4 hours per week

5-8 hours per week

9-12 hours per week

13-16 hours per week 17-20 hours per week More than 20 hours per week

6. How many years has your child been in the 4-H program?

Thank you so much for your time! Please return the completed questionnaire to your Extension Agent. 